\title{
VERGIL'S AENEID VIII AND THE SHIELD OF AENEAS: RECURRENT TOPICS AND CYCLIC STRUCTURES ${ }^{1}$
}

\author{
Horatio Caesar Roger Vella
}

\begin{abstract}
Book VIII of the Aeneid can be said to be the turning point in Aeneas' fulfilment of his mission indicated to him in Troy. In it Vergil formed two separate artistic structural patterns making up the length of the whole book while, at the same time, elaborating on the significance of the most symbolic object mentioned in the whole of the Aeneid, the Shield of Aeneas. This ecphrasis is characterized by literary embellishments, which compare well with those found in Homer's and Hesiod's poems. Both sections of this book are interrelated, since Hercules, in the site of the future Rome, foreshadows Aeneas, who then receives and lifts the shield representing, at its boss, Augustus' victory over Mark Antony and Cleopatra at the Battle of Actium. The book ends as it starts, the preparations being underway for the war against Mezentius.
\end{abstract}

\section{Introduction}

In the Aeneid, Vergil's subject matter is mythological, at least it appears to be. ${ }^{2}$ This mythological setting frequently refers indirectly to the author's contemporaneous history, ${ }^{3}$ by means of allegory; at times even directly through symbolism ${ }^{4}$, visions, prophecies and descriptions, including ecphrases.

In writing his Aeneid, Vergil kept in mind some techniques he had previously employed in both his Bucolics and his Georgics. These techniques included not only allegory, but also structure. The use of allegory employed in the various poems that form the Bucolics was sustained through that of the bees in Georgics $I V$, and here in the Aeneid. $^{5}$

Similarly, one can talk about the technique of parallel structures that appear in an inward analysis of the first nine poems of the Bucolics, starting from 1 and 9, and moving to 2 and 8 , etc. ${ }^{6}$ The Georgics, however, produce a tiered structure from the life of plants to the life of human beings, allegorised by the bees. The Aeneid's complex structure is evident not only in a comparison between various books of the epic, but also in an

\footnotetext{
1 I wish to thank Prof. Patricia A. Johnston, of Brandeis University, and the anonymous referees for SHT, for the views and remarks they kindly made on this paper. All texts in this paper are taken from R. A. B. Mynors ed., P. Vergili Maronis opera (Oxford, 1969).

${ }^{2}$ See R. D. Williams, 1967, 29-41, K. Quinn, 1968, and W. A. Camps, 1969. On the significance of the mythological Golden Age and its reflection on the author's contemporaneous times, see R. J. Rowland, $1968,832-842$.

${ }^{3}$ See A. J. Boyle, 1972, 63-90.

${ }^{4}$ See R. W. Cruttwell, 1946, V. Poeschl, 1962, and D. E. Eichholz, 1968, 105-112.

${ }^{5}$ On allegory in the Bucolics, see E. Coleiro, 1979. On the fourth Georgic, see J. Griffin, 1979, 61-68. On allegory in the Aeneid, see K. W. Gransden, 1973-1974, 14-27.

${ }^{6}$ See again E. Coleiro, 1979, 97-101.
} 
analysis of each particular book Vergil was composing. ${ }^{7}$ Of particular note is the climactic position VIII has in the second of three triads of books (V-VIII), IV and XII being the climaxes of the other two triads (I-IV and IX-XII). This triadic aspect also appears, according to some views, in the structure of Book VIII and even in the ecphrasis of the Shield within that book. ${ }^{8}$

\section{Aeneid VIII}

Book VIII of the Aeneid can be said to be the turning point in Aeneas' fulfilment of his mission indicated to him in Troy. Here, in the site of future Rome, Aeneas secures his alliances with both Evander and, through him, with the Etruscans. ${ }^{9}$ He also secures the backing of the gods, including gods formerly enemies to each other, Hercules and Juno. To establish peace, the forerunner of Augustus' Pax Romana, differences are forgotten. The Arcadians, relatives of former enemies, the Achaeans, ${ }^{10}$ are reconciled, while a people, whether Etruscan or Roman, will suppress a renegade leader, Mezentius or Antony.

To help achieve a significant connection of peoples, events and institutions, Vergil formed two separate artistic structural patterns making up the length of the whole book while, at the same time, elaborating on the significance of the most symbolic object mentioned in the whole of the Aeneid, the Shield of Aeneas. Both parts, including the digression of the Shield, are interrelated.

\section{Analysis of Aeneid VIII}

An analysis of Book VIII of Vergil's Aeneid will result in the observation that this book forms a cyclus in the way that it ends as it starts, the preparations being underway for the war against Mezentius. Inside this frame, two units, the first larger than the second, concentrate on the topics of Hercules' connection with Rome and the shield of Aeneas. The first schematic presentation forms an inner parallel structure (ABXBA), the second a chained one (ABAB). Both sections are interrelated, since Hercules, in the site of the future Rome, foreshadows Aeneas, who then receives and lifts the shield representing, at its boss, Augustus' victory over Mark Antony and Cleopatra at the Battle of Actium.

\footnotetext{
${ }^{7}$ On structure in the Aeneid, see W. A. Camps, 1954, 214-215, G. E. Duckworth, 1954, 1-15, G. E. Duckworth, 1957, 1-10, W. A. Camps, 1959, 53-56, G. E. Duckworth, 1960, 184-220, G. E. Duckworth, 1961, 2-11, G. E. Duckworth, 1962, P. Miniconi, 1963, 263-272, M. C. J. Putnam, 1965, J. W. Hunt, 1973, P. Salat, 1974, 167-184, E. L. Harrison, 1976, 101-112, and K. Quinn, 1968, 189-198.

${ }^{8}$ K. W. Gransden ed., 1976, esp. 4-7.

${ }^{9}$ See L. Ramaglia, 1958, 59-62, P. T. Eden, 1964-1965, 31-40, and W. Heilmann, 1971, 76-89.

${ }^{10}$ See Ch. P. Jones, 1995, 233-241, which discusses mythical kinships between Greeks and Romans portrayed in the Aeneid.
} 
The following is an analysis of the eighth book of the Aeneid.

$\begin{array}{llll}\text { A } & \text { Preparations } & 11.1-17 & 17 \text { lines } \\ \mathrm{Bi} & \text { Divine Aid } & 11.18-101 & 84 \text { lines } \\ \mathrm{Ci} & \text { Evander and Rome } & 11.102-183 & 82 \text { lines } \\ \mathrm{D} & \text { Hercules } & 11.184-305 & 122 \text { lines } \\ \mathrm{Cii} & \text { Evander and Rome } & 11.306-369 & 64 \text { lines } \\ \mathrm{Bii} & \text { Divine Aid } & 11.370-453 & 84 \text { lines } \\ \mathrm{Ei} & \text { War } & 11.454-519 & 66 \text { lines } \\ \mathrm{Fi} & \text { Shield } & 11.520-540 & 21 \text { lines } \\ \text { Eii } & \text { War } & 11.541-607 & 67 \text { lines } \\ \text { Fii } & \text { Shield } & 11.608-728 & 121 \text { lines } \\ & & & \\ \mathrm{G} & \text { Assumption of the Shield } & 11.729-731 & 3 \text { lines }\end{array}$

\section{Commentary on Aeneid VIII}

We note first that war is prepared not just against Aeneas at the very beginning of the book in lines 1-17 (A), but also, towards the end of the book in lines 454-519, against the Etruscans (Ei). Through Aeneas' coming to Evander at the site of the future Rome, two wars, one against the Trojans, the other against the Etruscans, and two enemies, Turnus and Mezentius, are fused together, with the result that Aeneas, the promised foreign hero, becomes the link in the two issues. With heaven's confirmation, he can now uplift the shield of the future Rome to stamp down resistance and arrogance addressed not only towards himself and his people, but also towards his new allies. This point will remind us of Rome's foreign policy towards her neighbours and clients, as she fought against third parties. Vergil himself anticipated such mission assumed here by Aeneas by reiterating the message given to Aeneas and his descendants:

Verg. A. 6.853: parcere subiectis et debellare superbos.

Next we encounter divine interventions, met with again both towards the beginning of the book in lines 18-101, and towards the end in lines 454-519, for not only does the River God Tiber predict the alliance of Aeneas with Evander (Bi), but also King Evander himself reveals the prophecy to Aeneas that the latter was to form an alliance with the Etruscans (Ei). Each of these predictions is followed by a miraculous sight, that of the sow with its litter $(\mathrm{Bi})^{11}$ and that of the heavenly sight of the promised arms (Fi).

Sacrifices are repeatedly mentioned. Towards the central part of the book, Aeneas first sacrifices to Juno (Bi), and then to Hercules (Ci and D). Thus, sacrifice in Book VIII involves two gods who were enemies to each other, Juno and Hercules, who here become the recipients satisfying different obligations: Juno, to allay her anger against the Trojans,

\footnotetext{
${ }^{11}$ See V. L. Johnson, 1961, 19-21, and G. Highet, 1973, 14-15, suggesting an additional line after 1.85. See also J. Thomas, 1999, 51-72.
} 
Hercules, to thank him for his past services to the Arcadians. In this way, enemies are either pacified (Juno), or eradicated (Cacus).

At Pallanteum itself, sacrifice with banquet is resumed twice: once in the woodlands after the arrival of Aeneas (D), and once at Pallanteum itself before Aeneas leaves the Arcadians (Eii). In the shield too we encounter a sacrifice, significantly that of another sow, by Romulus and Tatius (Fii).

The first meeting of Aeneas with the Arcadians in lines 102-183 (Ci) foreshadows the other meeting of Aeneas with the Etruscans in lines 541-607 (Eii). Both encounters take place by a river (Tiber and Caere), and in a woodland (the one dedicated to Hercules and the other to Silvanus). The first encounter not only foreshadowed the second, but also served as a necessary introduction to it, with Evander serving as the link.

The story of Hercules and Cacus ${ }^{12}$ features also in Prop. 4.9.1-22, Ov. F. 1.543586 and Liv. 1.7.3-12. Vergil's 184-305 (D) is an allegory of Aeneas and Mezentius within the same book, and of Augustus and Cleopatra in Roman history ${ }^{13}$. Just as Mezentius $^{14}$ allied himself with Turnus, who in the second half of the Aeneid is an allegory of Mark Antony, so also Cleopatra allied herself with Antony, and AeneasAugustus will fight against their joined forces. To confirm this allegory, Cacus' cave is situated on the future Aventine Hill, and the Salii, who also appear on the shield of Aeneas, celebrate the labours of Hercules. This last point can throw some light on the religious function of the Salii in Vergil's Rome ${ }^{15}$.

Aeneas' return from the woodlands in lines 306-369 (Cii) serves as Vergil's description, in the words of Evander,

a. of the earliest inhabitants of Rome, with reference to

b. some Roman quarters, still recognizable to Vergil's readers. ${ }^{16}$

\footnotetext{
12 See also H. Schnepf, 1959, 250-268, H. Bellen, 1963, 23-30, P. McGushin, 1964, 225-253, G. K. Galinsky, 1966, 18-51, C. Cuénot, 1967, 230-234, J. Sanz Ramos, 1968, 389-400, E. Paratore, 1971, 260-282, G. K. Galinsky, 1972 (1), 197, and G. K. Galinsky, 1972 (2), 131-149.

${ }^{13}$ On a different interpretation of Mezentius by Ovid in his Fasti, see D. Briquel, 1998, 3/4, 401-416. For a different view of Hercules in his allegory of Aeneas, see A. Ferenczi, 1998-1999, 327-334. Ferenczi, 332, further comments on the irony that Hercules had already shown the same brutality of Cacus when he had stolen the same cattle from Geryon (Pind. Fr. 169). More on the importance to history given by Vergil, see H. F. Bauzá, 1993, 205-213.

${ }^{14}$ More on Mezentius, see P. F. Burke, 1974, 202-209; D. Briquel, 1998, 401-416.

${ }^{15}$ P. T. Eden, 1973, 83, quotes Plutarch Camillus 30.1 referring to the return of the Romans under Camillus after the invasion of the Gauls around the 13th February. In this context, he considers the feast of the Lupercalia (15th February) and that of the Salii taking down the ancilia, sacred shields being tokens of divine protection traditionally modelled on a bronze original supposed to have dropped from heaven at Rome (Plut. Numa 13), in the Regia (24th March) as important. Vergil reminds us of these incidents twice through the Shield of Aeneas: Fii (above). Again Eden, 1975, comments on how the Salii bring together Evander and Augustus, the former the institutor, the latter the preserver of this priestly college. In his comment on Aen. 8.285 (p. 97-98), Eden refers to Vergil's association of the Salii with Hercules, and to how Hercules came to be venerated at this earliest trading settlement of the future Rome, the Forum Boarium, directly through the Greeks of the south, indirectly through the Etruscans, who we know perpetrated his cult and its connection with the Salii at Tibur. See also S. J. Harrison, 1997, 73, who emphasizes on the association of the Salii and the Luperci with the ancient site of Rome. Indeed, Ovid ( $F$. 2.381-424) alludes to both cults, including reference to the ancilia of the Salii, when he refers to the foundation of Rome.

${ }^{16}$ See D. Thompson, 1970, 147-153.
} 
This picture of primitive Rome is then balanced by

a. Vulcan's artistic representation of the future Rome on the shield of Aeneas in lines 608-728 (Fii), with reference to

b. heroes,

c. religious institutions

d. and the battle of Actium.

The site of the future Rome is thus not only visited personally by Aeneas, but is assumed by him on his shoulders when he lifts the shield (A. 8.731):

attollens umero famamque et fata nepotum.

Incidentally, this last line of Vergil's eighth book echoes the last line of his second book (A. 2.804): cessi et sublato montis genitore petivi,

when Aeneas here too lifts on his shoulders the future Rome, but through the person of his father Anchises ${ }^{17}$ who, in Vergil's projection of the concept of the pater as serving an important link between the ancestors and the future generations, will reveal the future Rome to his son in Book VI, in the Underworld. ${ }^{18}$

At Pallanteum, Aeneas' connection is not just with Hercules who, like him, is a hero and a demi-god ${ }^{19}$; who, like him, had lost a wife through folly (see Aeneid II), ${ }^{20}$ and who will shortly sleep in the same house ${ }^{21}$, but also with Evander, who, like him, had been banished from his country and who now shares a common enemy, Turnus.

The digression of Venus and Vulcan in lines 370-453 (Bii) is outflanked by lines 306-369 (Cii) and lines 454-519 (Ei).

a. In the former, Evander describes the earlier inhabitants of the district;

b. in the latter he describes his present neighbours, the Etruscans.

The shield, commissioned to Vulcan, is being prepared to protect the Etruscans, about to be introduced, and to install the descendants of Aeneas as the new inhabitants on the site of the future Rome just described.

The relationship of Evander with Pallas, his son (Eii), must remind us of a similar relationship of Aeneas with his son Ascanius throughout the Aeneid. The heart-rending separation of Pallas from Evander reminds us of Aeneas who leaves behind Ascanius by the river Tiber ${ }^{22}$. The ironic words of Evander, that he would not probably see his son again, are fulfilled in Aeneid 10.489, when Pallas was killed by Turnus.

\footnotetext{
${ }^{17}$ A point already made by P. McGushin, 1964, 240. See also J. R. T. Pollard, 1967-1968, 45.

${ }^{18}$ D. N. Levin, 1970, 35, comments that while in Aen. VI Anchises explained to Aeneas what he saw, in VIII Aeneas does not comprehend Vulcan's work.

${ }^{19}$ See further in M. Wigodsky, 1965 [1967], 218, where he mentions the errores and labores of the two heroes, their descent to the Underworld and their apotheosis.

${ }^{20}$ Both deaths were tragic. Aeneas in Aeneid II was at first on his way out of the burning Troy, in obedience to divine instructions, when he paused and turned back to offer further resistance, losing, in the process, his wife Creusa (738). In a different type of folly, Heracles killed his wife Megara after he was sent a fit of homicidal madness, ironically through another divine intervention, this time from Hera.

${ }^{21}$ P. McGushin, 1964, 233, 238-9. In this article, McGushin further compares Aeneas and Hercules to Atlas, related both to Aeneas and to Evander. The Latin word which Vergil uses here is regia (1.363). R. Rees, 1996, 583-586, supports Servius' view that this was so called to refer to the future Regia of Rome.

${ }^{22}$ More on this relationship of father and son and Aeneas' quality of pietas, see G. F. Butler, 1996-1997, $265-277$.
} 


\section{The Shield of Aeneas}

The Shield of Aeneas ${ }^{23}$ appears in the last part of the book. Following the description of the upstream journey of Aeneas to Pallanteum, the sacrifice of Potitius, the story of Hercules $^{24}$ and Cacus, the description of the early inhabitants of Rome and the quarters of the future city, and the account of King Evander about the dispute which the Lydian people of Agylla in Etruria had with their king Mezentius, who fled to the Rutulians, Goddess Venus indicates her sign of approval by the sight of the promised $\operatorname{arms}^{25}$ in heaven, which are described.

Ecphrasis, or topos, is a sub-genre whereby an author brings the narrative of events to a halt in order to offer pause for a detailed act of description. ${ }^{26}$ In Greek and

\footnotetext{
${ }^{23}$ On the Shield of Aeneas in general, see Ch. Ratkowitsch, 2001, 233-249, A. Barchiesi, 1997, 271-281, M. C. J. Putnam, 1998 (esp. 119-188), S. Bartsch, 1998, 322-342, S. J. Harrison, 1997, 70-76, B. W. Boyd, 1995, 71-90, M. C. J. Putnam, 1995, 107-133, S. Vilatte, 1991, 307-322, R. Cohon, 1991, 22-30, B. M. Giannatasio, 1988, 157-158, G. Ravenna, 1988, 739-742, R. O. A. M. Lyne, 1987, E. W. Hauck, 1985, J. Romeuf, 1984, 143-165, R. F. Thomas, 1983, 175-184, R. D. Williams, 1981, 8-11, J. Perret, 1978, esp. 216 ff., C. J. Fordyce, 1977, K. W. Gransden, 1976, esp. 14-20, D. A. West, 1975-1976, 1-6, R. D. Williams, 1973, D. S. Wiesen, 1973, 737-765, P. T. Eden, 1973, 78-83, J. G. Griffith, 1967-1968, 54-65, J. R. T. Pollard, 1967-1968, 41-53, D. E. Eichholz, 1966-1967, 45-49, F. Robertson, 1966-1967, 34-45, M. Wigodsky, 1965 [1967], 192-221, C. Becker, 1964, 111-127, F. Bömer, 1943-1944, 319-322, R. Heinze, 1914, esp. 401, H. T. Pluss, 1884, and J. Henry, 1883, Vol. III, esp. 775-776. As a contrast to the Shield of Aeneas, see M. R. Gale, 1997, 176-196. On ecphrasis in Vergil and Latin poets, see A. Szantyr, 1970, 28-40. S. Bartsch, 1998, 322, refers to four ecphrases in Vergil's Aeneid: Daedalus' relief, the temple of Juno, Aeneas' Shield and Pallas' belt, all four producing an opposition of control and violence, truth and deception, empire and chaos. B. W. Boyd, 1995, 71-90, refers to ecphrases in Aen. I, V, VI and VIII, and concludes that both what is depicted and the manner of depiction are necessary to see the described object (73). R. Cohon, 1991, 22-30, compares Aeneas' Shield with that of Athena Parthenos of Pheidias. Vergil's battle of Actium reminded the reader of Pheidias' Gigantomachy. The author makes the observation that Venus had stopped Vulcan and the Cyclopes, working at an aegis for Pallas Athena, to forge a shield for Aeneas instead (30). On shield in general, see M. Malavolta, 1988, 737-738, who distinguished between clipeus and scutum. On this distinction, see also J. G. Griffith, 1967-1968, 56.

${ }^{24}$ See J. W. Zarker, 1972, 34-48, and K. Gilmartin, 1968, 41-47. Zarker here quoted Seneca's De clementia 1.11 referring to arsit ira in Octavian's youth, and his later quality of mercy. It may be that the negative qualities of Hercules and his imitator Aeneas did not pass unnoticed by Augustus, of whom the two heroes were an allegory (46). Gilmartin, on the other hand, reveals various points which show dissimilarities between the two heroes.

${ }^{25}$ The peripeteia of the book in the sense that Aeneas, from being desperate and friendless, becomes, after this scene, the leader of several soldiers from other nations (P. T. Eden, 1975, xxi).

${ }^{26}$ M. C. J. Putnam, 1995, 107-108, who also enumerates six of these ecphrases, all with direct bearing on the meaning of the poem as a whole, and others centred on landscape. He notes that the one in VII referring to the stag is special in that no other refers to an animal, and has no Homeric precedent. On ecphrasis in general, see D. P. Fowler, 1991, 25-35. He refers to a common misconception that ecphrasis is simply a pause, to which nothing in the narrative corresponds at the level of story (25-26). One finds it difficult, however, to understand how narrative is about people and ecphrasis about things (26). See also N. Austin, 1966, 307. On ecphrasis in classical criticism, see A. S. Becker, 1992, 5, where he says that it is rarely mentioned. There we learn of two virtues of ecphrasis: $\sigma \alpha \phi \eta ́ v \varepsilon\llcorner\alpha$ (clarity) and ćvó (9). On ecphrasis in Greek and Latin literatures, see D. Pralon, 1988, 45, who refers to the Shields of Agamemnon and Aphrodite in the Iliad, noting that Zenodotus proposed to delete the ecphrasis of the Shield of Achilles because it was too long. See also F. I. Zeitlin, 1982, D. N. Levin, 1970, 31-35, J. Palm, 1967, esp. 108-211, J. L. Myers, 1930, esp. 517-523, and P. Friedländer ed., 1912, esp. 11-12. On shields in Greek art, see G. H. Chase, 1902, 61-127, who concludes that these shields, found in Greek art, refer to
} 
Roman epics, one encounters occasional pauses in the narrative which are employed by descriptions either of a military topic (e.g. shield) or of another topic (e.g. garden ${ }^{27}$, palace $^{28}$, mantle). These descriptions cover several lines, and are often decorated with literary embellishments. They are often symbolic and refer to the general concepts of society the poet has in mind. The writer encourages the reader to enter the world described but, at the same time, to remain aware of his relationship to the describer and the language of the description. ${ }^{29}$

\section{Analysis of the Shield of Aeneas}

The Shield of Aeneas consists of five parts ${ }^{30}$ covering 96 lines (608-728), that is, $13.13 \%$ of Book VIII, which are analysed as follows:

I $\quad 626-662(37$ lines $) \quad$ The Legendary

The descendants of Ascanius

Romulus and Remus suckling at the she-wolf ${ }^{31}$

The rape of the Sabine women ${ }^{32}$

The alliance of Romulus and Tatius

Tullus and Mettus ${ }^{33}$

Porsenna and Tarquin

Porsenna, and Cocles and Cloelia

Manlius and the Gauls ${ }^{34}$

$\begin{array}{ll}11.626-629 & 4 \text { lines } \\ 11.630-634 & 5 \text { lines } \\ 11.635-638 & 4 \text { lines } \\ 11.639-641 & 3 \text { lines } \\ 11.642-645 & 4 \text { lines } \\ 11.646-648 & 3 \text { lines } \\ 11.649-651 & 3 \text { lines } \\ 11.652-662 & 11 \text { lines }\end{array}$

II $\quad 663-670(8$ lines $) \quad$ The Institutional ${ }^{35}$

The Salii and the Luperci ${ }^{36} \quad 1.663 \quad 1$ line

the deed of the bearer, to the cult of some god, to the family of the bearer and to the country of the bearer (73).

${ }^{27}$ See P. Schubert, 1996, 255-263, and H. C. R. Vella, 1991, 149-152.

${ }^{28}$ See H. C. R. Vella, 1991, 160.

${ }^{29}$ A. S. Becker, 1992, 14.

${ }^{30}$ P. T. Eden, 1973, 80, quotes Vergil's introductory statement (res Italas Romanorumque triumphos ... pugnataque in ordine bella) to show that the list of encounters Rome had with its enemies is chronological. Emphasis is made not so much on the warfare, but on the triumphs of Rome culminating in Augustus' triumph after the battle of Actium.

${ }^{31}$ See J. Delz, 1966) 224-227.

32 D. S. Wiesen, 1973, 760, refers to the inclusion of the Sabine incident as jarring the quality of pietas visible in the whole tableau.

${ }^{33}$ On discussion on Mettus, see S. J. Harrison, 1997, 71.

${ }^{34}$ S. J. Harrison, 1997, 70-76, considers this list as a negative illustration of the defeats or near-defeats of Rome at the hands of her enemies.

${ }^{35}$ For a different view to taking this section as separate from its preceding one, see R. D. Williams, 1981, 11.

${ }^{36}$ See R. D. Williams, 1981, 9, P. T. Eden, 1973, 82-83, and G. Wissowa, 1912, esp. 555-561. S. Lonsdale, 1990, 26-27, shows how the Salii represent through song and mimesis the labours of Hercules. R. D. Williams, 1981, 9, says that the Salii safeguarded the sacred shields; the Luperci were associated 
The bonnets and the shields

The procession of the mothers

Tartarus and Catiline

Elysium and Cato ${ }^{37}$

III

IV
671-674 (4 lines) The Descriptive

675-723 (49 lines) The Historical ${ }^{38}$

Augustus with the Julian Star on his head ${ }^{39}$

Agrippa with the Naval Crown on his forehead

Antony and Eastern allies

Cleopatra $^{40}$ and her Egyptian allies

The ships compared to the Cyclades and

high mountains in motion

The queen rallies her forces

Egyptian gods against Roman gods

The rage of Mars

Strife and Bellona

Apollo and his bow

The retreat of the Egyptians ${ }^{41}$

The triumph of Augustus ${ }^{42}$

$\begin{array}{ll}1.664 & 1 \text { line } \\ 11.665-666 & 2 \text { lines } \\ 11.667-669 & 3 \text { lines } \\ 1.670 & 1 \text { line }\end{array}$

$\begin{array}{ll}11.678-681 & 4 \text { lines } \\ 11.682-684 & 3 \text { lines } \\ 11.685-686 & 2 \text { lines } \\ 11.687-688 & 2 \text { lines } \\ & \\ 11.689-695 & 7 \text { lines } \\ 11.696-697 & 2 \text { lines } \\ 11.698-699 & 2 \text { lines } \\ 11.700-701 & 2 \text { lines } \\ 11.702-703 & 2 \text { lines } \\ 1.704 & 1 \text { line } \\ 11.705-713 & 9 \text { lines } \\ 11.714-716 & 3 \text { lines }\end{array}$

with Evander, who saved the Trojans in Italy, while the matrons saved Rome during the Gallic invasion through the ransom of their gold. D. E. Eichholz, 1966-1967, 45, repeats Ward Fowler's idea that the scene of the Salii does not fit in this section, but was probably put there at the request of Augustus. However, in our division of sections separating the Institutional from those Legendary, this problem does not arise.

${ }^{37}$ See summary of discussion on which Cato is referred to here in S. Lewuillon, 1972, 1282. I think that I am right to point out that this section is to be separated from the preceding one; for Cato and Catiline do not belong to the legendary history of Rome. This last point is also admitted by R. D. Williams, 1981, 9.

${ }^{38}$ See A. Navara, 1986, esp. $89 \mathrm{ff}$. Vergil intended this part, the battle of Actium, to start from where the

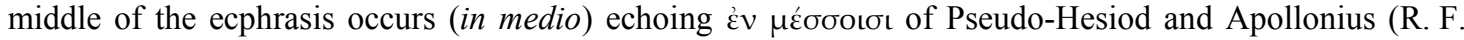
Thomas, 1983, 176-179).

${ }^{39}$ W. R. Nethercut, 1971-1972, 127, shows how the twin lights shining from Augustus' temples remind us of the two snakes in the Laocoon incident in Book II, the two snakes which Hercules kills in Book VIII, as well as of Iulus in II and Lavinia in VII. The twin beams signify the triumph of good over evil, the latter represented here by the twin snakes of Cleopatra further down.

${ }^{40}$ For a comparison of the treatment of Cleopatra by Vergil and Horace, see M. Encinas Martínez, 1997, 49-59.

${ }^{41}$ See A. Tronson, 1998, 31-50, M. Encinas Martinez, 1997, 49-59, and W. R. Nethercut, 1974, $20-23$. Nethercut here says that although historically there was only one snake which was offered to Cleopatra, Vergil applied the metaphor of the two snakes to relate to both the Laocoon's incident in Aen. II, Turnus' in VII and Hercules in VIII (20-22). On Vergil and the battle of Actium, see J. Thomas, 1991, 303-308, who comments on the relationship of the two snakes and twin lights in the passage, and the two doves mentioned at the beginning of Aen. VI (305), and on how the battle of Actium is a cosmic confrontation between disorder (East) and order (West) (308), and M. L. Paladini, 1958, who refers to the dominant position of Apollo during the battle, the importance of Agrippa, the opposition of Egyptian gods to Roman gods and the two snakes of Cleopatra. He also refers to Hor. Ep. 9 and C. 1.37, and Prop. 3.11.53.

${ }^{42}$ See P. Grimal, 1951, 51-61, and G. Binder, 1971. 
The celebration of Roman mothers ${ }^{43}$

11.717-719 3 lines

Augustus before the temple of Apollo

11.720-723 4 lines

V $\quad 724-728$ (5 lines) The Geographical

Numidians, Africans, Lelegeians, Carians and Gelonians

11.724-725 2 lines

The river Euphrates

$1.726 \quad 1$ line

The Morini and

the river Rhine

1.727

1 line

The Scythians and the river Araxes ${ }^{44}$

1.728

1 line

\section{Commentary on the Shield of Aeneas}

It will appear from the above analysis that in terms of lines dedicated to each of these five parts, Vergil meant to alternate I (37 lines) and IV (49 lines) with III (4 lines) and V (5 lines).

I and IV talk about the Roman people, first in their encounter with foreign powers, the Sabines, the Etruscans and the Gauls (I), and then with Egypt and her eastern allies (IV) ${ }^{45}$. Each conflict is described as crucial for the survival of Rome: ${ }^{46}$ increase in

\footnotetext{
${ }^{43}$ The presence of the mothers at the triumph of Augustus echoes that of the chaste mothers in their pilenta depicted in the Shield celebrating rites together with the Salii and the Luperci, for which comment see S. J Harrison, 1997, 73.

${ }^{44} \mathrm{~K}$. Toll, 1997, 34-56, interprets the multi-national element of these peoples as Vergil's own invitation to his audience for the fulfilment of a Roman commonwealth of foreigners. I. Ostenberg, 1999, 155-162, on the other hand, interprets them as really having been conquered by Augustus himself. S. J. Harrison, 1997, 75, notes that most of the tribes mentioned here had belonged to Antony, while the Geloni, Rhine and the Dahae represent distant peoples not yet conquered. See also U. Eigler, 1998, 289-305, A. G. McKay, 1998, 199-221, U. Huttner, 1997, 369-391, P. R. Hardie, 1986, esp. 346-347, D. Pietrusinski, 1977, 269275, R. J. Rowland, 1968, 832-842, and P. Boyancé, 1954, 220-249. According to A. G. McKay, 1998, 200, no complete examples of triumphal painting are extant. He imagines the Shield to have three concentric circles with two quartets of historical scenes, an emblema of triumphal parade and the sea assigned to the Actian battle (202).

${ }^{45}$ More on Roman society from Cicero, Vergil and Livy, see M. D. Dopico Caínzos, 1999, 139-161. A. G. McKay, 1998, 207, summarizes the contents of this part of the description as Rome's miraculous deliverances and heroic exploits, punishment, defeat and triumph. He quotes Gurval in the observation that the scenes here proceed in a swift and uneven movement (209). In the words of D. S. Wiesen, 1973, 737, the struggles pictured on the Shield have as their aim the rescuing of Italian independence and Italian ways from foreigners. But the grand conclusion of these efforts is the internationalisation of the Roman State. On a comparison of Vergil with Livy referring to the early history of Rome, see S. J. Harrison, 1997, 71-74.

${ }^{46}$ S. J. Harrison, 1997, 70-76. The moral qualities which helped Rome survive are fides, religio, pietas and iustitia (R. D. Williams, 1981, 10). D. E. Eichholz, 1966-1967, 45, quotes Ward Fowler in interpreting these scenes as escapes from terrible perils, ending with Actium. Eichholz (46) interprets the four virtues as virtus, clementia, iustitia and pietas.
} 
population, invasions, and treason. Three incidents in I match one in IV, and by this imbalance ${ }^{47}$ Vergil wants to show how important the Battle of Actium was for Augustus.

Section II is the Institutional part. This short passage, serving as a link between the Legendary part and the Battle of Actium, echoes Aeneid VI, which talks of ritual, religion, philosophy, Tartarus and Elysium ${ }^{48}$. Both the Salii and the Luperci celebrated Roman rituals, while the procession of the mothers at the triumph of Augustus (665666), another important Roman institution, stands in contrast to the procession of the fathers, that is, the ancestors of Elysium in the Underworld (6.760-886).

Section V, the Geographical part, matching section III, is intended to show the length and breath of the Roman Empire culminated in the rule of Augustus. A similar passage appears in 6.791-800, where the soul of Anchises in the Underworld predicts it to his son Aeneas. These two passages echo the passage in Catullus (11.1-11) where he sarcastically talks about his end of his affair with Lesbia, but wishes to announce this message to the length and breath of the empire.

\section{References to other Shields}

In the shield of Aeneas, reference is made to the shields which fell from heaven. The shield itself is a replica of those shields, which also were miraculously sent from heaven. In Aeneid III, Aeneas dedicates Abas' miraculous shield to that city's temple's god, Apollo, which he affixes to its door-post, and to which he attaches a poem (carmine) celebrating the event of the coming to Actium (rem ... signo). Already here Vergil introduces us to his concept of the miraculous shield, which he will develop further here in Book VIII. Both shields are miraculous; and both are related to Actium: one left there by Aeneas as a dedication to Apollo, the other itself representing the battle which was to be fought also there. Both shields are related to Hercules ${ }^{49}$.

Abas was the twelfth king of Argos, son of Lyncaeus and Hypermnestra, grandson of Danaus, and father of Acrisius and Proetus. When he informed his father of the death of Danaus, he was rewarded with the shield of his grandfather, which was sacred to Juno. This shield performed various marvels, and the mere sight of it could reduce a revolted people to submission ${ }^{50}$. Acrisius was the father of Danaë, who from Zeus bore Perseus. Perseus too carried with him the head of the Gorgon Medusa which turned into stone all who looked at it. Also, this head had a connection with a shield, that of Athena, into which it found its place as a gift from Perseus ${ }^{51}$. Perseus and his wife Andromeda bore Alcaeus and Electryon, fathers of Amphitryon and Alcmene respectively. Once more from Zeus, Alcmene, wife of her cousin Amphitryon, bore Hercules, who in the shield of Aeneas is given the great prominence we described above.

\footnotetext{
${ }^{47}$ A point already hinted at by J. G. Griffith, 1967-1968, 56. D. E. Eichholz, 1966-1967, 47, refers to the slower tempo the episodes here adopt until it stops by the battle of Actium.

${ }^{48}$ On the relationship of Aeneid VIII with other books of the epic, see W. A. Camps, 1954, 214.

${ }^{49}$ More on the relationship of Aeneid III and VIII, see P. V. Cova, 1999, 159-171.

${ }^{50}$ W. Smith, 1876, s.v. "Abas".

${ }^{51}$ W. Smith, 1876, s.v. "Perseus".
} 
Thus, Perseus, Heracles and Aeneas share in the following aspects: they are all demi-gods; they are all connected with Juno (both Hercules and Aeneas suffer directly through her interventions), and they are all connected with a shield.

\section{The Reaction on seeing the Shield}

On seeing the Shield, Aeneas first admires it before he observes the details,

619: $\quad$ miraturque inter manus et brachia versat

625: ... et clipei non enarrabile textum ${ }^{52}$,

and then, in three lines, which end the book, Vergil tells us that Aeneas again admires the shield (miratur) and lifts it with what future responsibilities it carries:

Talia per clipeum Volcani, dona parentis,

\section{0: $\quad$ Miratur...}

On two occasions in just seven lines each (655-661 and 671-677), Vergil accumulates the colours and minerals ${ }^{53}$ with which he describes the Shield by mentioning them seven times, sometimes twice in a verse $(655,659,673)$ or a run-on verse $(660-661)$, or three times (672), sometimes repeating them (659) or contrasting them (655). I quote the two passages which treat of the invasion of the Gauls and the battle of Actium, two most important incidences and dangers for Rome:

655: atque hic auratis volitans argenteus anser porticibus Gallos in limine adesse canebat; Galli per dumos aderant arcemque tenebant defensi tenebris et dono noctis opacae: aurea caesaries ollis atque aurea vestis,

660: virgatis lucent sagulis, tum lactea colla auro innectuntur, ...

haec inter tumidi late maris ibat imago aurea, sed fluctu spumabant caerula cano, et circum argento clari delphines in orbem aequora verrebant caudis aestumque secabant.

675: in medio classis aeratas, Actia bella, cernere erat, totumque instructo Marte videres fervere Leucaten auroque effulgere fluctus.

\footnotetext{
${ }^{52}$ See U. Eigler, 1994, 147-163.

53 About colours, perspectives, authorship, reactions, and positions in this ecphrasis, see also R. D. Williams, 1981, 10.
} 


\section{Conclusion}

Vergil, therefore, does not tell a plain story, but a highly symbolic one, a story with different layers of interpretation, though consistent in ultimately, but subtly, referring to the same person and message: Augustus and his triumph over his enemy. Some events recur through others, and so the effect is achieved in drilling into the reader's mind the message through repetition by parallelism. The Aeneid is, however, a spiritual book that Vergil composes: the triumph of good over evil, the reconciliation of the gods, and faith in divine promises. ${ }^{54}$ Furthermore, it is an artistic book, and in it Vergil succeeds to combine power of message, both political and spiritual, with artistic balances of passages and literary embellishments, such as those used in the ecphrasis. ${ }^{55}$

Dr. Horatio Caesar Roger Vella

University of Malta

Department of Classics and Archaeology

E-mail: horatio.vella@um.edu.mt

${ }^{54}$ See C. Gargiulo, 1950, F. Sforza, 1952, T. J. Haarhoff, 1959, 5-15, F. A. Sullivan, 1959, 150-161, and J. P. Poe, 1965, 321-336.

${ }^{55}$ See W. S. Anderson, 1969. 


\section{References}

Anderson, W. S. 1969. The art of the Aeneid. (Landmarks in literature.) (Englewood Cliffs, N.J., Prentice-Hall)

Austin, N. 1966. "The function of digressions in the Iliad", GRBS 7, 307

Barchiesi, A. 1997. "Virgilian narrative: ecphrasis". In Ch. Martindale, ed. 1997, 271281

Bartsch, S. 1998. "Ars and the man: the politics of art in Virgil's Aeneid", CPh 93, 4, $322-342$

Bauzá, H.F. 1993. "El arte poético de Virgilio como prefiguración de la historia", Helmantica 44, 205-213

Becker, A. S. 1992. "Reading poetry through a distant lens: ecphrasis, Greek rhetoricians and the Pseudo-Hesiodic Shield of Herakles", AJPh 113, 5-24

Becker, C. 1964. "Der Schild des Aeneas", WS 77, 111-127

Bellen, H. 1963. "Adventus Dei. Der Gegenwartsbezug in Vergils Darstellung der Geschichte von Cacus und Hercules (Aen. VIII.184-275)", RhM 106, 23-30

Binder, G. 1971. Aeneas und Augustus. Interpretationen zum 8. Buch der Aeneis. (Beiträge zur klassischen Philologie 38.) (Meisenheim, Hain)

Bömer, F. 1943-1944. "Studien zum VIII Buche der Aeneis", RhM 92, 319-322

Boyancé, P. 1954. "Le sens cosmique de Virgile", REL 32, 220-249

Boyd, B. W. 1995. "Non enarrabile textum: ecphrastic trespass and narrative ambiguity in the Aeneid", Vergilius 41, 71-90

Boyle, A. J. 1972. "The meaning of the Aeneid. A critical inquiry, I: Empire and the individual. An examination of the Aeneid's major theme", Ramus 1, 63-90

Briquel, D. 1998. "Le personage de Mézence dans les Fastes: Érudition et poésie, ou Ovide entre Verrius Flaccus et Virgile", REA 100, 3/4, 401-416

Burke, P. F. 1974. "The role of Mezentius in the Aeneid", CJ 69, 202-209

Butler, G. F. 1996-1997. "Fathers and sons in Vergil's Aeneid and book 6 of Paradise Lost", CML 17 (3), 265-277

Camps, W. A. 1954. "A note on the structure of the Aeneid", CQ 48, 214-215

Camps, W. A. 1959. "A second note on the structure of the Aeneid", CQ 53, 53-56

Camps, W. A. 1969. An introduction to Virgil's Aeneid. (Oxford, Oxford University Press)

Chase, G. H. 1902. "The shield devices of the Greeks", HSPh 13, 61-127

Cohon, R. 1991. "Vergil and Pheidias: the Shield of Aeneas and of Athena Parthenos", Vergilius 37, 22-30

Coleiro, E. 1979. An introduction to Vergil's Bucolics with a critical edition of the text (Amsterdam, Grüner)

Cova, P. V. 1999. "Dal libro terzo all'ottavo dell' Eneide: dal passato verso il futuro", Aevum(ant) 12, 159-171

Cruttwell, R. W. 1946. Virgil's mind at work. An analysis of the symbolism of the Aeneid (Oxford, Blackwell)

Cuénot, C. 1967. "Une comparaison littéraire. L'épisode d'Hercule et de Cacus chez Virgile", IL 19, 230-234

Delz, J. 1966. "Die säugende Wölfin auf dem Schild des Aeneas”, MH 23, 224-227 
Dopico Caínzos, M. D. 1999. “Aeternitas o desaparición de Roma? Dos visiones de la sociedad romana", QUCC N.S. 63, 139-161

Duckworth, G. E. 1954. "The architecture of the Aeneid", AJPh 75, 1-15

Duckworth, G. E. 1957. "The Aeneid as a trilogy", TAPhA 88, 1-10

Duckworth, G. E. 1960. "Mathematical symmetry in Vergil's Aeneid", TAPhA 91, 184220

Duckworth, G. E. 1961. "Tripartite structure in the Aeneid", Vergilius 7, 2-11

Duckworth, G. E. 1962. Structural patterns and proportions in Vergil's Aeneid (Michigan, Ann Arbor, University of Michigan Press)

Eden, P. T. 1964-1965. "The Etruscans in the Aeneid", PVS 4, 31-40

Eden, P. T. 1973. "The Salii on the Shield of Aeneas: Aeneid 8.663-666", RhM 116, 7883

Eden, P. T. 1975. A commentary on Virgil, Aeneid VIII. (Mnemosyne Supplement 35.) (Leiden, Brill)

Eichholz, D. E. 1966-1967. "The Shield of Aeneas. Some elementary notions", PVS 6, $45-49$

Eichholz, D. E. 1968. "Symbol and contrast in the Aeneid", G\&R 15, 105-112

Eigler, U. 1994. "Non enarrabile textum (VERG. Aen. 8.625). Servius und die römische Geschichte bei Vergil”, Aevum 68, 147-163

Eigler, U. 1998. "Augusteische Repräsentationskunst als Text?: zum Problem der Erzählbarkeit von bildender Kunst in augusteischer Dichtung am Beispiel des Schildes des Aeneas", Gymnasium 105, 4, 289-305

Encinas Martínez, M. 1997. "Cleopatra lírica/Cleopatra épica”, $C F C(L)$ 13, 49-59

Ferenczi, A. 1998-1999. "The double-faced Hercules in the Cacus-episode of the Aeneid", ACD 34-35, 327-334

Fordyce, C. J. 1977. P. Vergilii Maronis Aeneidos libri VII-VIII (Oxford, Clarendon)

Fowler, D. P. 1991. "Narrate and describe: the problem of ekphrasis", JRS 81, 25-35

Friedländer, P. ed. 1912. Johannes von Gaza und Paulus Silentarius: Kunstbeschreibung justinianischer Zeit (Leipzig, Berlin)

Gale, M. R. 1997. "The Shield of Turnus (Aeneid 7.783-792)", G\&R Ser. 2, 44, 2, 176196

Galinsky, G. K. 1966. "The Hercules-Cacus episode in Aeneid VIII", AJPh 87, 18-51

Galinsky, G. K. 1972 (1). "Hercules and the hydra (Vergil Aen. 8.299-300)", CPh 67, 197

Galinsky, G. K. 1972 (2). The Herakles theme: the adaptations of the hero in literature from Homer to the 20. century (Oxford, Blackwell)

Gargiulo, C. 1950. La religiosità di Virgilio nella figura di Enea (Messina, D’Anna)

Giannatasio, B. M. 1988. Texo. In Enciclopedia virgiliana VI (Rome), 157-158

Gilmartin, K. 1968. "Hercules in the Aeneid", Vergilius 14, 41-47

Gransden, K. W. 1973-1974. "Typology, symbolism and allegory in the Aeneid", PVS $13,14-27$

Gransden, K. W. 1976. ed., Virgil: Aeneid Book VIII (Cambridge, Cambridge University Press)

Griffin, J. 1979. "The fourth Georgic, Virgil and Rome", G\&R N.S. 26, 61-68

Griffith, J. G. 1967-1968. "Again the Shield of Aeneas (Aeneid 8.625-731)", PVS 7, 54 65 
Grimal, P. 1951. "Énée à Rome et le triomphe d'Octave", REA 53, 51-61

Haarhoff, T. J. 1959. "The experience of Aeneas as a test of faith", Orpheus 6, 5-15

Hardie, P. R. 1986. Virgil's Aeneid. Cosmos and Imperium (Oxford, Clarendon)

Harrison, E. L. 1976. "Structure and meaning in Vergil's Aeneid", Papers of the Liverpool Latin Seminar, 101-112

Harrison, S. J. 1997. "The survival and supremacy of Rome: the unity of the shield of Aeneas", JRS 87, 73

Hauck, E. W. 1985. Vergil's contribution to ekphrasis (Dissertation, Ohio State University)

Heilmann, W. 1971. "Aeneas und Evander im achten Buch der Aeneis", Gymnasium 78, $76-89$

Heinze, R. 1914. Virgils epische Technik (Leipzig, Teubner)

Henry, J. 1883 [repr. in 1972]. Aeneidea (New York), Vol. III

Highet, G. 1973. "A dissertation on roast pig”, $C W 67,14-15$

Hunt, J. W. 1973. Forms of glory. Structure and sense in Virgil's glory (Illinois, Carbondale, Southern Illinois University Press)

Huttner, U. 1997. "Hercules und Augustus (in der Aeneis)", Chiron 27, 369-391

Johnson, V. L. 1961. "The case for Vergil's venerable pig", Vergilius 7, 19-21

Jones, Ch. P. 1995. "Graia pandetur ab urbe", HSPh 97, 233-241

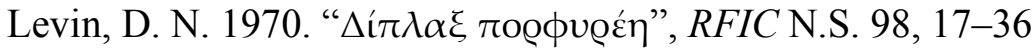

Lewuillon, S. 1972. "Virgile, Énéide, VIII, 670. Caton d’Utique ou Caton le Censeur?", RBPh 50, 1282

Lonsdale, S. 1990. "Simile and ekphrasis in Homer and Virgil", Vergilius 36, 26-27

Lyne, R. O. A. M. 1987. Further voices in Vergil's "Aeneid" (Oxford, Clarendon)

Malavolta, M. 1988. Scudo. In Enciclopedia virgiliana IV (Rome), 737-738

Martindale, Ch. ed. 1997. Cambridge companion to Virgil (Cambridge; New York, Cambridge University Press)

McGushin, P. 1964. "Virgil and the spirit of endurance", AJPh 85, 225-253

McKay, A. G. 1998. Non enarrabile textum? The Shield of Aeneas and the triple triumph of 29B.C. (Aeneid 8.630-728). In H. P. Stahl ed. 1998, 199-221

Miniconi, P. 1963. "Les proportions mathématiques dans l'Énéide", Latomus 22, 263 272

Myers, J. L. 1930. Who were the Greeks? (Berkeley, University of California Press)

Mynors, R. A. B. ed. 1969. P. Vergili Maronis opera (Oxford, Clarendon)

Navara, A. 1986. Poésie virgilienne de la mémoire. Questions sur l'histoire dans l'Énéide 8 (Clermont-Ferrand, Adosa)

Nethercut, W. R. 1971-1972. "The imagery of the Aeneid", CJ 67, 127

Nethercut, W. R. 1974. "Snakes in the Aeneid. Two comments", Vergilius 20, 20-23

Ostenberg, I. 1999. "Demonstrating the conquest of the world: the procession of peoples and rivers on the shield of Aeneas and the triple triumph of Octavian in 29 B.C. (Aen. 8.722-728), ORom 24, 155-162

Paladini, M. L. 1958. A proposito della tradizione sulla battaglia di Azio. (Coll. Latomus 35.) (Brussels-Berchem)

Palm, J. 1967. Bemerkungen zur Ekphrase in der griechischen Literatur. Kungl. Humanistiska Vetenskaps-Samfundet i Uppsala, Arsbok 1965-1966 (Stockholm) 
Paratore, E. 1971. Hercule et Cacus chez Virgile et Tite-Live. In Vergiliana: Roma aeterna III (Leiden, Brill), 260-282

Perret, J. 1978. Virgile, Énéide VIII (Paris, Les Belles Lettres)

Pietrusinski, D. 1977. "De comparatione Apollinis cum Augusto in VIII libro Aeneidos tamquam de genere extollendi principem ad deos" (vv. 675-728)", Meander 32, 269-275

Pluss, H. T. 1884. Vergil und die epische Kunst (Leipzig, Teubner)

Poe, J. P. 1965. "Success and failure in the mission of Aeneas", TAPhA 96, 321-336

Poeschl, V. 1962. The art of Vergil. Image and symbol in the Aeneid (Michigan, Ann Arbor, University of Michigan Press)

Pollard J. R. T. 1967-1968. "Something odd about Virgil”, PVS 7, 41-53

Pralon, D. 1988. "Le Bouclier d'Achille", IL 40, 45

Putnam, M. C. J. 1965. The poetry of the Aeneid. Four studies in imaginative unity and design (Harvard, Cambridge, Harvard University Press)

Putnam, M. C. J. 1995. "Silvia's stag and Virgilian ekphrasis", MD 34, 107-133

Putnam, M. C. J. 1998. Virgil's epic designs (New Haven (Conn.), Yale University Press)

Quinn, K. 1968. Virgil's Aeneid. A critical description (London, Routledge and Kegan Paul)

Ramaglia, L. 1958. "La leggenda di Evandro", RSC 6, 59-62

Ratkowitsch, Ch. 2001. "Eine historische Lücke in der vergilischen Schildbeschreibung (Aen. 8.626-728)", WS 114, 233-249

Ravenna, G. 1988. Scudo di Enea. In Enciclopedia virgiliana IV (Rome), 739-742

Rees, R. 1996. "Revisiting Evander at Aeneid 8.363", CQ N.S. 46 (2), 583-586

Robertson, F. 1966-1967. "Allegorical interpretations of Virgil”, PVS 6, 34-45

Romeuf, J. 1984. "Le Bouclier d'Énée (Aen. 626-731): imagination picturale et création littéraire", REL 62, 143-165

Rowland, R. J. 1968. "Foreshadowing in Vergil, Aeneid 8.714-728”, Latomus 27, 832842

Salat, P. 1974. "Symétries et correspondances numérique dans l'Énéide”, REL 52, $167-$ 184

Sanz Ramos, J. 1968. La leyende de Hércules y Caco en Virgilio y en Livio. In Actas III. Congreso español de Estudios clásicos II (Madrid), 389-400

Schnepf, H. 1959. "Das Herculesabenteuer in Virgils Aeneis VIII, 184f.", Gymnasium 66, 250-268

Schubert, P. 1996. "Le palais d'Alcinoos et les Panathénées", REG 109, 1, 255-263

Sforza, F. 1952. Il più prezioso tesoro spirituale d'Italia, l'Eneide (Milan, Gastaldi)

Smith, W. 1876. A smaller classical dictionary of biography, mythology and geography (London, Murray)

Stahl, H. P. ed. 1998. Vergil's Aeneid. Augustan epic and political context (London, Duckworth)

Sullivan, F. A. 1959. “The spiritual itinerary of Virgil's Aeneas", AJPh 80, 150-161

Szantyr, A. 1970. "Bemerkungen zum Aufbau der virgilianischen Ekphrasis", $M H$ 27, $28-40$

Thomas, J. 1991. "Le sens symbolique de la bataille d'Actium (Enéide 8.671-728)", Euphrosyne N.S. 19, 303-308 
Thomas, J. 1999. La truie blanche et les trente gorets dans l'Énéide de Virgile. In Ph. Walter ed. 1999, 51-72

Thomas, R. F. 1983. "Virgil's ekphrastic centrepieces", HSPh 87, 175-184

Thompson, D. 1970. "Allegory and typology in the Aeneid", Arethusa 3, 147-153

Toll, K. 1997. "Making Roman-ness and the Aeneid", ClAnt 16, i, 34-56

Tronson, A. 1998. "Vergil, the Augustans, and the invention of Cleopatra's suicide: one asp or two?", Vergilius 44, 31-50

Vella, H. C. R. 1991. "Some novel aspects in Homer's Odyssey and Longus", SIFC 9, 2, $149-152$

Vilatte, S. 1991. "Pensée et esthétique chez Virgile: le bouclier d'Énée", LEC 59, $307-$ 322

Walter, Ph. ed. 1999. Études mythologies du porc: actes du colloque de Saint-Antoine l'Abbaye (Isère) (Grenoble, Millon)

West, D. A. 1975-1976. "Cernere erat. The Shield of Aeneas", PVS 15, 1-6

Wiesen, D. S. 1973. "The pessimism of the eighth Aeneid", Latomus 32, 737-765

Wigodsky, M. 1965 [1967]. "The arming of Aeneas", C\&M 26, 192-221

Williams, R. D. 1967. "The purpose of the Aeneid", Antichthon 1, 29-41

Williams, R. D. 1973. The Aeneid of Vergil, Books 7-12 (London, Macmillan)

Williams, R. D. 1981. "The Shield of Aeneas", Vergilius 27, 8-11

Wissowa, G. 1912 [2nd edition]. Die Religion und Kultus der Römer (München, Beck)

Zarker, J. W. 1972. "The Hercules theme in the Aeneid", Vergilius 18, 34-48

Zeitlin, F. I. 1982. Under the sign of the shield: semiotics and Aeschylus' "Seven against Thebes" (Rome, Ateneo) 